\title{
Knowledge and Awareness Regarding Antibiotic Usage and Resistance among General Population in Delhi-NCR Region
}

\author{
Aditi Sharma ${ }^{1}$, Akshat Sachdeva ${ }^{1}$, Sumit Bhateja ${ }^{2, *}$, Geetika Arora ${ }^{3}$
}

\section{Aditi Sharma', Akshat Sachdeva ${ }^{1}$, Sumit Bhateja $^{2, *}$, Geetika Arora ${ }^{3}$ \\ 'Dental Surgeon, Manav Rachna Dental College, Faridabad, Haryana, INDIA. \\ ${ }^{2}$ Department of Oral Medicine and Radiology, Manav Rachna Dental College, Faridabad, Haryana, INDIA. ${ }^{3}$ Department of Public Health Dentistry, Inderprastha Dental College, Sahib- abad, Uttar Pradesh, INDIA.}

\section{Correspondence}

Dr. Sumit Bhateja,

Department of Oral Medicine and Radiology, Manav Rachna Dental College, Faridabad, Haryana, INDIA.

Mobile no: +919891353960

Email: sumit.mrdc@mrei.ac.in

History

- Submission Date: 20-09-2019;

- Revised Date: 10-10-2019;

- Accepted Date: 11-11-2019;

DOI : 10.5530/ijmedph.2019.4.31

Article Available online

http://www.ijmedph.org/v9/i4

\section{Copyright}

(C) 2019 Phcog.Net. This is an openaccess article distributed under the terms of the Creative Commons Attribution 4.0 International license.

\begin{abstract}
Aim: To assess the knowledge and awareness related to antibiotic usage and resistance amongst general population. Materials and Methods: A total of one thousand citizens (of age group 25 - 65 years) from Delhi-NCR participated in this study. A questionnaire survey comprising of ten questions relating to knowledge and awareness of antibiotic usage were completed by the participants. Results: It was observed that $74 \%$ of people rarely used antibiotics. Also, $55 \%$ believed that misuse/overuse of anti-microbial drugs is harmful and can have adverse effects on our body. A large fraction comprising of about $60 \%$ are affected by infections on a yearly basis. Conclusion: A majority of the population of our community believed in using antibiotics without having the necessary knowledge and awareness regarding its proper use. Key words: Knowledge, Awareness, Attitude, Antibiotics, Resistance.
\end{abstract}

\section{INTRODUCTION}

The discovery of antibiotics is considered one of the most important achievements in the field of medicine. They can be classified as follows:

\section{Classification of Anti - Microbial Drugs}

Although there are many systems for classification, the most useful is based on chemical structure. Antibiotics within a structural class will generally have similar patterns of effectiveness, toxicity and allergic potential.

The chief classes of antibiotics are: ${ }^{1}$

1. Beta-Lactams

2. Penicillins

3. Cephalosporins

4. Macrolides

5. Fluoroquinolones

6. Tetracyclines

7. Aminoglycosides

Most commonly used antibiotics are: Aminoglycosides, Penicillins, Fluoroquinolones, Cephalosporins, macrolides and Tetracyclines. While each class consists of multiple drugs, each drug is peculiar in its own way.

Although the antibiotics are known to have wide variety of uses in treating many infectious diseases, still inappropriate usage practices can invariably lead to development of resistance towards wide range of pathogens. Once resistance has been developed, it is difficult for it to be reversed and hence it will be a tough task to treat infections caused by various disease causing organisms. ${ }^{2}$ The irrational and over consumption of antibiotics can not only lead to the formation of bacterial strains that are resistant but also in various adverse reactions and also become a potent financial burden. ${ }^{3}$ This irrational use can be attributed to various economic factors and healthcare policies concerning about medical insurance, lack of physicians and antibiotics sale without prescription from a registered practitioner in some countries. ${ }^{4}$ Despite several interventions over the years to promote rational use of antimicrobial drugs, rapid spread of bacterial resistance and poor patient compliance still continues to be a global challenge worldwide. ${ }^{5}$

The general public does play an inevitable role in reducing the inappropriate use of antibiotics. While there are numerous review publications around the world regarding this topic, a population-based study was needed to assess the understanding about antibiotic usage amongst general population of the country. Keeping this background in mind, the present study was carried out in order to assess knowledge and awareness regarding antibiotic usage and resistance amongst citizens. The study also aims to increase public awareness with respect to the same and to identify targets for quality improvement.

\section{MATERIALS AND METHODS}

A self-administered questionnaire survey comprising of 10 questions was formulated by an Oral Medicine specialist and two dental surgeons. The questionnaire was validated.

The survey was conducted among a total of one thousand people (of age group 25-65 years) residing in Delhi-NCR region over a period of six months 
(March' 19 - August' 19). The questionnaire survey was distributed to the citizens at public places (metro stations, bus stops, malls etc.) and they were asked to fill it according to their will after taking informed consent from each of the participants. They had to only select the best suitable answer from the given options for the pertaining question. The questions were designed for the purpose of assessing knowledge and awareness regarding antibiotic usage and resistance. The study was approved by the Institutional Ethical Committee.

\section{RESULTS}

It was observed that $74 \%$ people rarely used antibiotics. A large fraction comprising about $65 \%$ experienced that the antibiotic they were taking for a long period of time was not effective anymore, indicating the development of antibiotic resistance. Also 55\% believed that misuse or overuse of anti-microbial drugs can be harmful and have adverse effects on the body. Almost $65 \%$ of the citizens who participated do not purchase antibiotics with proper written prescription from a registered practitioner. A mixed response was obtained when asked whether the participants followed complete course of antibiotics. The results of our survey have been summarized in Table 1 .

\section{DISCUSSION}

The basic purpose behind designing this study is to prevent the emergence of antibiotic resistance. Results showed that there is lack of awareness among the community that the use of antibiotics can develop resistance pattern. Almost $21 \%$ of people in our study developed monthly infections. This is in accordance to a study conducted in 2015 wherein nearly $20 \%$ of people developed monthly infections. ${ }^{6}$ It can be concluded from this figure that the spread of infetions is not occurring at a very rapid pace. The emergence of resistant bacterial strains to antimicrobial agents is of great concern worldwide. ${ }^{7}$ Among other factors, the irrational use of antibiotics has contributed to the bacterial resistance with substantial clinical and economic impact. ${ }^{8}$ In the present study, the level of awareness was not found up to the mark as $61 \%$ of people follow last prescription and take antibiotic on their own without prior consultation. The primary barrier can be attributed to the fact that prescribers feel that-the more it is, the better it is in eliminating the infection. This false belief is considered to be a major obstacle in preventing antibiotic resistance among the population. It is therefore necessary and of utmost importance to conduct educational campaigns that are aimed to improve the general population's knowledge on this topic. For example, the European Antibiotic Awareness Day, ${ }^{9}$ organized by the European Centre of Disease Prevention and Control every year beginning in the year 2008, emphasizes the need for both general practitioners and European citizens to use antimicrobial drugs responsibly. Other campaigns conducted in Belgium, England and France ${ }^{10,11}$ that used high-impact tools such as television and that were repeated for several years resulted in an improving of antibiotic use and attitudes. The attitudes towards antibiotic use indicated that nearly $65 \%$ of respondents were of the opinion that they would take an antibiotic without a prescription of a physician or health care professional. A cross sectional survey conducted in Italy revealed that only $22.7 \%$ people take self-medication without a proper prescription which is in extreme contrast with the results of our present study. ${ }^{12}$ Another survey conducted in China demonstrated that nearly $87 \%$ of patients showed non - compliance with use of antibiotics and did not follow the complete course as prescribed. ${ }^{13}$ This is in contrast with the results of our study where $26 \%$ did not follow the complete course. Possible reasons for non-compliance include fear of adverse effects caused by long term use, improvement in symptoms and complexity of the treatment. ${ }^{13}$ In terms of practice, the role of pharmacies needs to be mentioned. They have an important role in contributing to public knowledge

\begin{tabular}{|c|c|c|c|c|}
\hline $\begin{array}{l}\text { S. } \\
\text { No. }\end{array}$ & QUESTION & & RESPONSE & \\
\hline 1. & $\begin{array}{c}\text { How often you get } \\
\text { infections? }\end{array}$ & $\begin{array}{l}\text { Monthly : } \\
21 \%\end{array}$ & $\begin{array}{l}\text { Weekly : } \\
19 \%\end{array}$ & $\begin{array}{l}\text { Yearly : } \\
60 \%\end{array}$ \\
\hline 2. & $\begin{array}{c}\text { How often do you use } \\
\text { antibiotics? }\end{array}$ & $\begin{array}{l}\text { Mostly : } \\
26 \%\end{array}$ & $\begin{array}{l}\text { Rarely: } \\
74 \%\end{array}$ & \\
\hline 3. & $\begin{array}{l}\text { Do you always } \\
\text { purchase antibiotics } \\
\text { with doctor's } \\
\text { prescription? }\end{array}$ & $\begin{array}{l}\text { Yes : } \\
35 \%\end{array}$ & $\begin{array}{l}\text { No : } \\
65 \%\end{array}$ & \\
\hline 4. & $\begin{array}{l}\text { If not then do you } \\
\text { seek advice from } \\
\text { any health care } \\
\text { professional? }\end{array}$ & $\begin{array}{l}\text { Yes : } \\
38 \%\end{array}$ & $\begin{array}{l}\text { No: } \\
62 \%\end{array}$ & \\
\hline 5. & $\begin{array}{l}\text { Have you ever } \\
\text { followed last } \\
\text { prescription and } \\
\text { taken antibiotics on } \\
\text { your own? }\end{array}$ & $\begin{array}{l}\text { Very Often : } \\
61 \%\end{array}$ & $\begin{array}{l}\text { Rarely : } \\
19 \%\end{array}$ & $\begin{array}{l}\text { Never : } \\
20 \%\end{array}$ \\
\hline 6. & $\begin{array}{l}\text { Have you experienced } \\
\text { any of the minor or } \\
\text { serious adverse effects } \\
\text { of antibiotics? }\end{array}$ & $\begin{array}{l}\text { Yes : } \\
44 \%\end{array}$ & $\begin{array}{l}\text { No : } \\
56 \%\end{array}$ & \\
\hline 7. & $\begin{array}{l}\text { Do you follow } \\
\text { complete course of } \\
\text { antibiotics? }\end{array}$ & $\begin{array}{l}\text { Yes : } \\
38 \%\end{array}$ & $\begin{array}{l}\text { No : } \\
26 \%\end{array}$ & $\begin{array}{l}\text { Sometimes : } \\
36 \%\end{array}$ \\
\hline 8. & $\begin{array}{l}\text { Have you ever } \\
\text { experienced that } \\
\text { the antibiotic you } \\
\text { were taking was not } \\
\text { effective anymore? }\end{array}$ & $\begin{array}{l}\text { No: } \\
65 \%\end{array}$ & $\begin{array}{l}\text { Yes : } \\
22 \%\end{array}$ & $\begin{array}{l}\text { Don't Know } \\
13 \%\end{array}$ \\
\hline 9. & $\begin{array}{c}\text { Do you know that } \\
\text { misuse/overuse of } \\
\text { antibiotics can be } \\
\text { harmful? }\end{array}$ & $\begin{array}{l}\text { Yes : } \\
55 \%\end{array}$ & $\begin{array}{l}\text { No : } \\
45 \%\end{array}$ & \\
\hline 10. & $\begin{array}{l}\text { Has your doctor ever } \\
\text { increased the dosage } \\
\text { of antibiotics over } \\
\text { period of time? }\end{array}$ & $\begin{array}{l}\text { Yes : } \\
36 \%\end{array}$ & $\begin{array}{l}\text { No : } \\
64 \%\end{array}$ & \\
\hline
\end{tabular}

about appropriate antibiotic usage, as more fractions of the respondents stated that they obtained information on antibiotic use from pharmacies rather than from doctors.

Practitioners also have a pivotal role in the prevention of resistance. It is their moral duty to correctly inform the patients on the risk of antimicrobial drug misuse and at the same time, should not be overwhelmed by patients' requests. Health care providers should be foreseen as important and trustworthy components of any health education and promotional program.

Education can act as a potential source to stop the misuse of antibiotics and thereby prevent antibiotic resistance. The students in various healthcare professional colleges should be made aware of all the facts in order to evoke a sense of responsibility among them that they as future practitioners do play a major role. Undergraduate teaching, hence should just not inculcate the training of antibiotic prescribing but also cover the protocol for use of antibiotics in health care sector. The findings in the present study should also alert educators in various institutions and they should not just aim at increasing the knowledge but also ponder 
upon training to bring about efficient methods in order to bring about a change for the purpose of improving the treatment efficacy.

Few of the limitations of this study include that the data gathered is subjective as the response was based solely on respondents' memory. Also, some key factors (including family income, health status etc.) of the participants were not analyzed.

\section{CONCLUSION}

Under the limitations of the present study, it can be concluded that the people exhibit a fair knowledge and awareness about antibiotic usage patterns. This needs to be more worked upon and incorporated in practice by conducting educational campaigns across cities to generate awareness and solve the emergence of antibiotic resistance. In addition, the practitioners should make their patients aware regarding the importance of a correct behavior concerning antibiotic consumption.

\section{CONFLICT OF INTEREST}

The authors declare conflict of interest.

\section{REFERENCES}

1. http://www.emedexpert.com/classes/antibiotics.shtml\#3

2. Wolff MJ. Use and misuse of antibiotics in Latin America. Clin Infect Dis. 1993;17 (Suppl 2):S346-51.
3. Gyssens IC. Quality measures of antimicrobial drug use. Int J Antimicrob Agents. 2001;17(1):9-19.

4. Metlay JP, Stafford RS, Singer DE. National trends in the use of antibiotics by primary care physicians for adult patients with cough. Arch Intern Med. 1998;158(16):1813-8.

5. Pechere JC, Hughes D, Kardas P, Cornaglia G. Non-compliance with antibiotic therapy for acute community infections: A global survey. Int J Antimicrob Agents. 2007;29(3):245-53.

6. Naveed S, Qamar F, Maqsood A, Ayub A, Kauser H, et al. Prevalence and Consequences of Misuse of Antibiotics, Survey Based Study in Karachi. J Bioequiv and Bio Availab. 2015:7(5):202-4

7. Spellberg B, Guidos R, Gilbert D, Bradley J, Boucher HW, Scheld WM, et al. The epidemic of antibiotic-resistant infections: A call to action for the medical community from the Infectious Diseases Society of America. Clin Infect Dis. 2008;46(2):155-64.

8. Maragakis LL, Perencevich EN, Cosgrove SE. Clinical and economic burden of antimicrobial resistance. Expert Rev Anti Infect Ther. 2008;6(5):751-63.

9. McNulty CAM. European Antibiotic Awareness Day 2012: General practitioners encouraged to TARGET antibiotics through guidance, education and tools. J Antimicrob Chemother. 2012;67(11):2543-6.

10. Sabuncu E, David J, Bernède-Bauduin C, et al. Significant reduction of antibiotic use in the community after a nationwide campaign in France, 2002-2007. PLoS Med. 2009;6(6):e1000084.

11. Lambert MF, Masters GA, Brent SL. Can mass media campaigns change antimicrobial prescribing? A regional evaluation study. J Antimicrob Chemother 2007;59(3):537-43.

12. Napolitano F, Izzo MT, DiGiuseppe G, Angelillo IF. Public Knowledge, Attitudes and Experience Regarding the Use of Antibiotics in Italy. PLoS One. 2013;8(12):1-6.

13. Tong S, Pan J, Lu S, Tang J. Patient compliance with antimicrobial drugs: A Chinese survey. American Journal of Infection Control. 2018;46(4):25-9.

Cite this article : Sharma A, Sachdeva A, Bhateja S, Arora G. Knowledge and Awareness Regarding Antibiotic Usage and Resistance among General Population in Delhi NCR Region. Int J Med Public Health. 2019;9(4):145-7. 